\title{
Cognitive Authorities in Health Education Classrooms: A Nexus Analysis on Group- Based Learning Tasks
}

\section{Introduction}

Socio-technical developments have revolutionized access to information and led to a shift from centralized authorities to mass collaboration (Lankshear \& Knobel, 2011). In the rapidly changing information environments, implying a proliferated diversity of information providers and multimodal texts, learners face challenges in judging what to accept as true (see Rescher, 2013). To foster critical thinking, developing young people's information literacycompetencies in seeking, selecting, and evaluating information (Sormunen, Tanni, Alamettälä, \& Heinström, 2014) - is a challenge that needs to be addressed by practitioners in librarianship and school education (Smith, 2013).

In school settings, transformations regarding the authority of information can be increasingly observed. The teacher's monopoly of knowledge is questioned (Hanell \& Salö, 2015), while learners' agency and collaborative practices of information seeking, construction, evaluation, and use are increasingly emphasized (Hirvonen, Nygård, Palmgren-Neuvonen, Huhta, \& Huotari, 2019). When using information sources representing different practices of knowledge production (McKenzie, 2003; Wilson, 1983), learners should recognize different types of authorities and consider the origins, context, and suitability of the information created and shared by these potentially authoritative entities (Association of College and Research Libraries, 2015). Doing so can provide meaningful opportunities for developing learners' information literacy, but it can also lead to tension as traditional classroom practices are challenged. This empirical, qualitative study employs nexus analysis (Scollon \& Scollon, 2004) to explore how these authorities emerged in group-based knowledge-construction projects in health education lessons.

\section{Problem statement}

It has been claimed that systems that organize the production and consumption of information in society, including the educational system, are based on a centralized, exclusionary, and unitary notion of authority (Whitworth, 2014). Scollon and Scollon (2004) describe the traditional classroom as "a panopticon" where the teacher is "at the hub of the communication wheel" (p. 39). Supported by the physical arrangement of a classroom that places the teacher at the front of the room separated from the students, a panopticon classroom typically includes "platform events" (a person performing for the observation of an audience) and "meetings" (a group with relatively equal status in their rights to take the floor) (see Goffman, 1983). In a panopticon classroom, the teacher in either setting is able to control when, what, and how students talk (Scollon \& Scollon, 2004), manipulating the classroom discourse according to their pedagogical purposes (Alexander, 2005; Staarman \& Mercer, 2010). With syllabusdefined and teacher-controlled discourse, the purpose is to learn what authorities (researchers, authors, and teachers) have to say; students' discourse is evaluated based on how well they have adopted the language, concepts, and arguments of the given text (Scollon \& Scollon, 2004).

The ideals of learner agency, participation, collaborative learning, and aspects of text production (New London Group, 1996), drawing on and implying multiliteracy ${ }^{1}$, have

\footnotetext{
${ }^{1}$ Multiliteracy — or multiliteracies (New London Group, 1996) — fall broadly under a new literacies umbrella (Coiro, Knobel, Lankshear, \& Leu, 2008) and was initially presented as a pedagogy involving a sociocultural approach to learning, emphasising two "multis" in modes of meaning-making, namely, different cultural or
} 
challenged the panopticon interaction order, specifically traditional roles of teachers and students. These ideals are also likely to transform classroom information practices, the socially and culturally established ways to identify, seek, use, and share information (Savolainen, 2008; see also Talja \& Nyce, 2015) and can make room for distributed, participatory, and multivoiced authority (Whitworth, 2014).

While a considerable body of empirical research on authority in classroom settings has looked at authority as a power relationship between the teacher and students (e.g., Shor, 2014; Macleod, MacAllister, \& Pirrie, 2012), this study pays particular attention to the authority of information sources and draws from the concept of cognitive authority, referring to those sources people deemed credible and legitimate (Wilson, 1983). The study explores how cognitive authorities emerge in group-based knowledge-construction projects in health education lessons, asking: (a) how is cognitive authority distributed, and (b) in what ways do participants co-construct cognitive authorities in these settings?

\section{Literature review}

\subsection{Cognitive authority}

The concept of cognitive authority refers to information sources - human or non-human - that people deem credible and legitimate and that can influence their thinking (Wilson, 1983). Rather than mere status, such as administrative authority, it is based on, for example, the reputation and perceived expertise of a source. People are usually considered to have cognitive authority at least in the sphere of their own experience (Wilson, 1983). Though conceptions of cognitive authorities are understood as subjective accumulations of beliefs, knowledge, and experiences (Rieh, 2010), they are viewed as socially constructed (e.g., McKenzie, 2003). In different communities and spheres of knowledge, different authorities are recognized (Wilson, 1983). Accordingly, the assessment of the potential cognitive authority is highly contextual, closely linked to people's conceptions of setting and type of information (Hirvonen, Tirroniemi, \& Kortelainen, 2019). Rather than "accurate representations of pre-existing beliefs or attitudes," cognitive authorities have been considered "examples of everyday fact construction" (McKenzie, 2003, p. 263), built and contested with discursive strategies (McKenzie, 2003; Neal \& McKenzie, 2011), and used as cultural tools in credibility assessment (Mansour \& Francke, 2017; Sundin \& Francke, 2009).

Research on cognitive authority construction in school contexts has looked at students' strategies to evaluate (Limberg, 1999) and negotiate the authority of sources (Sundin \& Francke, 2009) and ways authority is distributed in classrooms (Stroupe, 2014). Limberg (1999) found most students evaluate the authority of sources based only on exterior signs (e.g., experts' position or lack of expert terminology in a text) rather than the content. In a study by Sundin and Francke (2009), students used multiple strategies to determine and negotiate the plausibility of claims: they relied on their previous knowledge, paid attention to authority transferred to texts from trusted organizations, people, genre, or medium (e.g., book, website), and compared sources with each other. Stroupe (2014), in turn, evidenced that teachers can purposefully either redistribute cognitive authority to students or position them as passive receivers of information and reproducers of canonical ideas.

social contexts (Cope \& Kalantzis, 2016) and multimodality in texts, typical of students' everyday lives (Tan \& Guo, 2014). However, in recent literature, multiliteracy is viewed as a set of communication abilities (Palsa \& Ruokamo, 2015) and competences to obtain, interpret, produce, and evaluate diverse kinds and forms of text in different forms, in different environments and situations, and by using various tools (Halinen, Harmanen, \& Mattila, 2015). These competences relate closely to those conceptualised as information literacy. 


\subsection{Group-based knowledge construction in schools}

Research on information literacy and related practices, that is, the ways information is identified, sought, used, and shared as part of school work, indicates that the focus of information literacy education seems to be shifting from locating information sources to using information in knowledge construction (Diekema, Holliday, \& Leary, 2011), and collaborative practices are increasingly used (Sormunen et al., 2014). It also suggests that assignments that engage learners in collaborative information seeking and knowledge construction ${ }^{2}$, implementing the ideas of multiliteracy, afford opportunities to enhance learners' critical thinking and associated competencies (Sormunen et al., 2014). These objectives imply a shift from the transmission-and-acquisition model of teaching (Sawyer, 2006) towards practices that enable students to use and share information derived from multiple sources, challenging the teacher's monopoly of knowledge (see Hanell \& Salö, 2015; Bourdieu, 2014). Such tasks can prompt shared meaning-making, contributing to the development of understanding on information content and offering further possibilities for negotiations on credibility.

However, the literature also reveals shortcomings: students tend to have difficulties in information seeking (Hongisto \& Sormunen, 2010) and credibility evaluation (Kiili, Leu, Marttunen, Hautala, \& Leppänen, 2018). Teachers, in turn, have been found to overestimate students' abilities to independently learn information practices (e.g., Sormunen, Alamettälä, \& Heinström, 2013; Smith, 2013).

\subsection{Nexus analysis}

This study is guided by a nexus analytical approach, the methodological application of mediated discourse analysis (Scollon, 2001). Nexus analysis, drawing from, with principled eclecticism (Hult, 2015), different research traditions, such as ethnography, critical discourse analysis, and action research, enables the analysis of not only what is done and said (ethnographic content) but also how (discourses) and why (motives) (Scollon \& Scollon, 2004). Rather than focusing on a priori social group or culture, it takes social action as its starting point, viewing any action as inherently social and mediated (Lane, 2014). By exploring the connections of action and discourse (Scollon \& de Saint-Georges, 2012), it focuses on discourse in action (Wohlwend, 2014), unlike traditional discourse analysis that examines language itself (Lane, 2014). Discourses are not understood as mere language use but as key processes to construct, contest, and legitimize our worlds (Scollon \& Scollon, 2004) and as 'a social language', manifested, for instance, in the physical arrangement of a classroom (Scollon \& Scollon, 2003).

Nexus analytical viewpoints that focus on teasing out the relevant elements in any social action (Martinviita, 2017) are discourses in place, interaction order, and historical body (Scollon \& Scollon, 2004). Discourses in place are the discursive elements that circulate throughout any social action, influencing interaction by enabling certain interactions and inhibiting others (Martinviita, 2017). The focus is on those discourses that mediate action, that is, used as mediational means by the actors (Lane, 2014). Nexus analysis makes use of Goffman's (1983) concept of interaction order to describe the "social arrangements by which we form relationships in social interactions" (Scollon \& Scollon, 2004, p. 13). These arrangements may imply, for example, the roles and positions taken in social interaction. Although people tend to adhere to their culturally and historically shaped roles (Räisänen, 2015), different people play the same role differently, driven by their history or personal

\footnotetext{
2 The concept of knowledge construction is used synonymously with knowledge building, referring to the premise that, rather than acquiring knowledge, learners actively build it in a process where individuals and the social interact in a cycle (Scardamalia \& Bereiter, 2006).
} 
experience (Scollon \& Scollon, 2004). Accordingly, guided by tacit agreements about the rules of the interaction order, people act differently depending on the context and social setting. The notion of historical body refers to each participant's previous experiences, learned practices, and understandings. Since it is shaped by lived interaction orders and discourses, historical body is unique to each individual (Scollon \& Scollon, 2004). These three key aspects are intertwined and are reciprocally shaped at a specific moment in time in the nexus of practice (Lane, 2014).

Rather than being a strict methodology, nexus analysis offers analytical tools to help understand social action in the interpersonal, community, and societal levels (Hult, 2017), making its historicity and situatedness visible (Martinviita, 2017). Through the central tasks of engaging, navigating, and changing ${ }^{3}$ the nexus of practice (Scollon \& Scollon 2004), nexus analysis allows a wide degree of freedom to employ any relevant data or analytical tool(s) found useful for studying social actions (Norris \& Jones, 2005). Instead of focusing solely on participants' views, on discourses, or on interaction in situ, nexus analysis attempts to reveal how single moments of social action are nexus points where different trajectories or discourse cycles meet.

\section{Methodology}

\subsection{Empirical setting and sampling}

The context of the present qualitative study is health education, which, in Finland, is a mandatory subject in secondary schools (grades 7-9). According to the recently introduced Finnish core curriculum (Finnish National Board of Education, 2016), the objective and theoretical framework of this subject is health literacy, involving not only theoretical and practical knowledge on basic health issues but also competencies to find and critically evaluate health information (Paakkari \& Paakkari, 2012). Overall, the Finnish core curriculum, based on a sociocultural approach to learning, stresses learners' active involvement and collaborative knowledge construction (Scardamalia \& Bereiter, 2006) that link, like the broad conception of texts, to multiliteracy, one of the cross-curricular competence areas (Finnish National Board of Education, 2016).

The study began by identifying relevant scenes and actors (Scollon \& Scollon, 2004) for the study. To follow the ethnographic spirit of nexus analysis, the researchers aimed to gain access to health education classrooms applying group-based tasks, for a longer period, to observe and understand social action. A dozen health education teachers in two secondary schools were contacted, and five of them agreed to let the researchers visit their lessons; three teachers with their students (56 in total) volunteered to participate in the further study by implementing a group-based knowledge-construction project.

As is typical with an ethnographic approach, the researchers played an active role. Prior to each project, the researchers had a meeting with the teacher to discuss mutual expectations regarding the group task that would engage students to seek information and build knowledge together. The students were informed about the researchers' long-term presence to observe their group work and the associated emphasis on productive dialogic interaction and the evaluative group discussions regarding information and information sources. The teachers were encouraged to plan and implement their projects (labeled as Cases 1 to 3, C1-C3) according to their own teaching philosophy and pedagogical aims.

\footnotetext{
${ }^{3}$ The researcher engages with relevant scenes and actors and then moves to more carefully navigating and mapping the key cycles of discourse, people, and mediational means involved in the action. Through these actions, the researcher also changes the nexus of practice (Scollon \& Scollon 2004).
} 


\subsection{Data collection}

A group of four researchers collected data in the spring semester of 2017 by observing and recording classroom activities in all project phases using three digital video cameras and several audio recorders. At least two researchers at a time were present in each session, the second author in all sessions. In total, 17 hours, 25 minutes of classroom activities were observed and 41 hours of video recorded ${ }^{4}$. In the group sessions, it was not possible to closely observe each group working in the classroom, and the groups to be observed were randomly selected. In the classrooms, the researchers were positioned as observers, except where some episodes required engagement as observer-as-participant to prompt some groups to concentrate on their joint task.

In addition to observational data, 1) the groups were briefly interviewed during the sessions to find out what kinds of information sources the groups used; 2) students of two classes, 19 girls and 14 boys, were interviewed, either before $(\mathrm{C} 1$, eight interviews, $\mathrm{N}=16$, ranging from 29 to 42 minutes; total 286 minutes) or after (C3, eight interviews, $N=17$, ranging from 18 to 35 minutes; total 218 minutes); and 3) the teachers were interviewed after the respective project $(58,60$, and 61 minutes, respectively). To save time and allow interaction between the participants, the students were interviewed in groups of two, excluding two that took place in single or triadic setting. The interviews were semi-structured and focused on students' health information practices, health education in school, and classroom practices. Teacher interviews dealt with their pedagogical principles and practices prompting collective information evaluation. The analysis reported in this article focuses on the video recordings, albeit with some interviews quoted, labeled as Interview_Case_Group, e.g., I_C3_3B. It is worth noting that $\mathrm{C} 1$ and $\mathrm{C} 2$ involved classes for music-oriented students while $\mathrm{C} 3$ participants were more heterogeneous.

\subsection{Data analysis}

To examine "what is actually going on, not what ought to go on" (Glaser, 1978, p. 14) and to more closely navigate social action at the micro and macro levels (and any in-between), the researchers transcribed, qualitatively analyzed and annotated a total of 27 hours of video recordings using QSR NVivo. Iterative phases of open coding and constant comparison helped to identify crucial cycles of discourses, people, places, and mediational means (Scollon \& Scollon, 2004) that were connected to classroom information practices. Rather than to exhaustively code the data, the aim was to outline the interactional structure and elements and highlight meaningful fragments within it to consider the habits associated with the three interwoven elements of social action (see Scollon \& Scollon, 2004).

Triangulation, a pivotal framework for nexus analysis, was implemented across the research processes. The data collected by the researchers (two, three, or four of them, depending on the case) was immediately discussed, including their observations and interpretations (researcher triangulation) with a variety of participants at different times (participant triangulation) and settings using observation, audio and video recordings, and interviews (data and method triangulation). This contributed to the credibility and trustworthiness of this qualitative study (Twining, Heller, Nussbaum, \& Tsai, 2017). The researchers' collaborative analysis involved repeated viewings of the corpus of interest to agree on major events, transitions, and themes. Selected excerpts, translated from Finnish by the authors, are presented to appropriately exemplify the findings and allow transparent and, thus, more reliable consideration of the prevailing issues.

The researchers worked within the guidelines for research ethics in empirical research along with the consent procedures in the humanities, social, and behavioral sciences (Finnish

\footnotetext{
${ }^{4} 27$ hours excluding some less-valuable episodes of administrative practices or unclear recordings.
} 
Advisory Board on Research Integrity, 2012). Prior to data collection, the students, with the written consent of their guardians, agreed to participate in the study and to be recorded for research purposes. For further confidentiality and data protection, the authors have withheld the demographic details and the exact date and place of the studies, and used code names or pseudonyms in all reports. The teachers were given code names T1, T2, and T3.

\section{Findings}

\subsection{Distributing cognitive authority}

This section addresses the first research question by paying particular attention to how the classroom interaction order - together with discourses and social actors with their historical bodies - enabled the distribution of cognitive authority. The observed social actions appeared to be guided by broad discourses deriving from the core curriculum, involving pedagogical goals, domain content, competence objectives, and assessment criteria (see Finnish National Board of Education, 2016) as well as those connected to general school practices, such as classroom seating and teacher turn-allocation. However, each classroom, lesson, and group formed a unique interaction order.

In each case, the groups produced a shared artifact, i.e. media content about a topic included in the curriculum. In $\mathrm{C} 1$, the groups created posters on special diets; $\mathrm{C} 2$ produced PowerPoint presentations on chronic and infectious diseases; and C3 made short documentary videos on physical activity. However, the different task designs (Table 1) and practices establishing the circumstances for social interaction influenced the trajectories of classroom actions.

\section{[Table 1]}

Various information sources and channels were used in each case, creating opportunities for the distribution of cognitive authority across the teacher, students, and print and online sources. These multiple sources were enabled differently in the projects, depending on the availability of materials, source recommendations, and tools for information seeking (see Table 2), for example.

\section{[Table 2]}

In $\mathrm{C} 1$ and $\mathrm{C} 2$, the groups worked in the same room within the immediate field of the teacher's vision, either in the information and communication technology (ICT) classroom equipped with laptops or in the ordinary classroom where tablets and smartphones could be used. Health education textbooks and note-taking tools (pencils and paper) were also available. In C3, the groups were scattered around the school building with their smartphones and note-taking tools outside the teacher's vision except in Session 2, which was conducted with the teacher's physical presence in the computer classroom. Students in C3 also filmed teacher and student interviews. In all spaces, students had access to the Internet.

\subsubsection{Opening and closing the tasks in whole-class settings}

The task focused on group work but there were also platform events (see Scollon \& Scollon, 2004) in each class with either the teacher or students in groups positioned in front of the class. Platform events allowed the teachers to introduce the task, center the classroom talk on the 
agenda and, in whole-class review sessions, to ensure that the groups had fulfilled the task requirements.

Each project started with a short teacher-led orientation to introduce the task (structure, goal, and requirements) in a whole-class setting. T1 first designated the students to study the basics of the theme (special diets) on their own using the health education textbook and settled upon a fast-paced recitation asking, for instance: "Why do we need vitamin B? Who can read from the table? Miisa?" Indicating a single authority model, T1 advised the students to read the correct answers from the textbook and, with closed-ended questions allowed short answers only. Employing practices that follow a traditional classroom interaction order, T1 emphasized the recitation script, implementing a panopticon: "Shh! If you have something to say, raise your hand and tell us all," inviting the students to indicate their "activity."

To start the group phase, T1 assigned students to form groups of up to three members, to select a special diet from a list (e.g., gluten-free or low-carbohydrate diet) and to examine why people choose to follow those diets, what kinds of health impacts may emerge, and how the possible harmful effects of the diet can be managed. T1 recommended hand-written posters as output modes, although the groups were allowed to make PowerPoint presentations or videos as well. This phase encouraged the students to seek information from various online sources and discuss several diets together to be able to select the most interesting one.

In $\mathrm{C} 2$, the task entailed seeking relevant information about one of the chronic or infectious diseases common among Finns and make PowerPoint presentations describing, for instance, its causes, diagnosis, and treatment. T2 designated the topics to the pre-selected groups, emphasizing that the task aimed "not to train you to become medical professionals but enhance your competence to take care of yourselves and your family members." Although allowing the use of self-sought online sources, T2 provided the students with a link list, printed leaflets, and health education, biology and psychology textbooks, this promoted the use of these particular sources.

T3, informed by a documentary video model, assigned pre-selected groups to examine the pros and cons of physical activity and who, where, and when physical activity applies according to the guideline form linked to the model. T3 instructed the class to begin by creating a mind map in groups to help plan the video, encouraging students to come up with their own ideas: "There are no right answers ... the point is not to have the same things for everyone." Although T3 talked about online information seeking for the whole class in the beginning of the first and second sessions and despite the plentiful time allocated to planning, the task did not prompt groups to seek subsequent information in this phase, even in Session 2 (75 minutes) conducted in the computer classroom. Rather, the groups appeared to draw from their previous knowledge and experiences to plan the narrations to introduce and summarize the content and message.

All projects were concluded with whole-class reviews to present the group products. In these review events, students can be seen to be positioned as authorities, teaching others what they had learned during the task. Moreover, in $\mathrm{C} 1$ and $\mathrm{C} 2$, the plentiful time allocation (two to three lessons, equally as much as the phase of information seeking and knowledge construction) left room for common discussion and shared reflection on the topics. C3 provided a contrast: T3's invitation to comment on the presented group-generated videos did not engender classroom talk, and the "premiere" took mere 25 minutes. In C1 and C2 most groups provided references to the sources they had used, but the teachers' attention seemed to be focused on the content, and sources were not discussed or were commented on only briefly: "Yes, these sound like reliable sources" (T2). 


\subsubsection{Working in groups}

When working together in groups, students could participate in building knowledge from multiple sources without the teacher controlling the discourse. However, implicit norms and teachers' expectations, for example, seemed to guide students' activities. Most students took up their shared task enthusiastically. In $\mathrm{C} 1$ and $\mathrm{C} 2$, the tasks prompted the groups to build knowledge together and create their joint artifact (poster or presentation). Practically all of the students participated and contributed to group dialogue around the ICT tools and information sought with them. Usually, one of the members took the role of scribe, while other members sought information; the roles were frequently circulated. Some groups decided to divide their task into subtasks that appeared to be implemented individually. The traditional setting of desks and chairs (or fixed tables in the ICT classroom, which made the group members sit side by side) did not seem to hamper group dialogue and collaboration, especially required in some $\mathrm{C} 2$ groups struggling with very complex information content. For instance, the topic group for influenza strived to understand the difference between common cold and influenza, and the topic group for allergies, despite their efforts to make sense of terms and concepts, occasionally invited T2 to facilitate the development of their understanding.

Even in those groups collaborating enthusiastically, group talk seemed to focus on the appearance and spelling of texts to be written in their shared artifact rather than its content. The groups stressed the need not to "take it directly word for word from the source" and, with respect to the forthcoming class review, to put the texts written in their slides in other words in the oral presentation not to merely read them out loud. These viewpoints made them elaborate the content of the sources. During the sessions, the teachers did not discuss the ground rules of information use or giving presentations, excluding the reminder to keep a reference list (possibly prompted by the researchers' pronounced expectations on getting to know what kinds of information sources the groups used), a requirement that the groups appeared to follow.

In the planning phase of $\mathrm{C} 3$, the participants, rather than seeking subsequent information for their joint video, suggested ideas representing their personal views, seemingly relying on their previous understanding, their "own experience" [I_C3_4A]. In the reflective interviews, some students explained that they, at that point, did not need further information. All the groups used interviews, suggested in the guidelines, as one of the inquiry methods. The interviews with teacher and student informants, used as a material for the videos, were filmed in Session 5. Monitored and scaffolded less than in the other cases, the groups tended to increasingly concentrate on topics and experiences relevant and interesting for them, engaging in either individual smartphone activities or sharing YouTube videos about moped-speeding, for instance. Group interaction thus emerged very differently from $\mathrm{C} 1$ and $\mathrm{C} 2$, and from what the researchers had expected from an active learning perspective.

\subsection{Co-constructing cognitive authorities}

Although the use of multiple sources could be expected to create fruitful situations for negotiating cognitive authorities, the information content or credibility of sources were rarely discussed. Rather, cognitive authorities were legitimated and delegitimated in subtle ways. The following sub-sections focus on the second research question by examining how cognitive authorities were co-constructed in the classrooms.

\subsubsection{Using teacher-selected materials}

Health education textbooks were used in each classroom at some point to introduce the task or build a basic understanding of key concepts. This was particularly so in $\mathrm{C} 1$ where the students were assigned to begin the task by reading a 12-page section of the textbook, presenting the 
relationship between diets and vitamins. While students' judgments on the textbooks varied, the teachers promoted their use by stating that they include "very good information" [T3] and "explain things clearly" [T2].

In $\mathrm{C} 2$, the groups used a link list and printed leaflets pre-selected by $\mathrm{T} 2$, who claimed: "I've taken these articles from magazines [published by health authorities]. They shouldn't be hooey, as I have accepted them." The groups justified the use of teacher-selected sources based on a known authority or authoritative-sounding name, e.g., "I think the NIHW is still quite credible because it is the National Institute of Health and Welfare." Overall, the groups seemed not to challenge the credibility of these pre-selected sources. They even used such sources to contest the teacher's authority, as in Excerpt 1 that exemplifies a critical information negotiation between the participants' different understandings.

Excerpt 1. C2, whole-class review: Contesting the teacher's authority.

T2: Wait a minute. You claimed that the symptoms can be relieved using antibiotics? Antibiotics don't work against viruses.

Riina: Multiple sources suggested that-

T2: But symptoms-

Riina: One of the sources suggested that some bacteria-caused symptoms can be treated using antibiotics, not the virus-caused symptoms.

Susa: Yeah, influenza may go away on its own, but symptoms can be relieved using antibiotics.

T2: I doubt it. No physician will prescribe antibiotics for virus-caused disease to relieve symptoms, but often there's some post-influenza infection such as bronchitis or sinusitis... they are bacterial.

Riina: We had the source, the handout, it was in there.

T2: Ok, I'll check it.

As indicated in the excerpt, the students' understanding conflicting with the teacher's stance provoked meaning-making between the teacher and topic group Influenza. The excerpt also shows how whole-class settings create opportunities to discuss information from different sources, reflect on important issues, and develop a shared understanding on presented conceptions.

Teacher-selected materials suggested that T2 aimed to lead the groups to find some specific expected facts. This was also evidenced by her inquiry to topic group Asthma about particular pieces of information in their presentation: "Did you mention about the two types of asthma drugs? Or the blow-bottle treatment?"

\subsubsection{Drawing from personal experiences}

Students in C3 relied heavily on their experiences and previous knowledge in the planning phase of the project. Also in $\mathrm{C} 1$ and $\mathrm{C} 2$, the students gained information not only from external sources but also the group members' personal experiences. For example, in $\mathrm{C} 1$, a celiacaffected participant aimed to explain villous atrophy in topic group Digestive diseases' poster using her own experience: "Shall I write this? Because that's why I can't use ordinary butter."

Interestingly, in many groups, one of the members or a person close to them was affected by an allergy or disease included the group's topic, which clearly inspired them to disseminate their knowledge and learn about the issue in-depth, indicating authentic information needs. The dialogue presented in Excerpt 3, taking place in the whole-class review between the Allergies group presenters (Tiina and Anna) and audience members (Virpi and Kirsi), shows how several students' personal experiences were brought into the discussion. 
Excerpt 2. C2, whole-class review: Multiple experts-by-experience.

Virpi: I got rid of my milk allergy by eating milk products as much as possible.

Anna: Do you mean like desensitization?

Tiina: Did you stay at the hospital for the desensitization?

Virpi: Yeah.

Anna: Then it was desensitization.

Kirsi: It begins... if you have a very severe type of allergy so that you can die of being in touch with the allergen... it can be started by pouring a little drop of milk and-

Tiina: Then gradually give it more and more to make you less sensitive.

Kirsi: Yes, my brother was also cured like that...

The excerpt shows experiential cognitive authority as the participants report their similar experiences and reinforced each other's position as cognitive authorities in this disease.

\subsubsection{Googling}

In C1 specifically, the groups used Google as a self-evident information-seeking tool, returning not only formal websites but also those of a less traditionally authoritative nature, such as blogs and online forums. Observing the initially scarce evaluative talk in the groups, T1 (who frequently brought up issues and findings emerging in groups to the whole-class discussion though the emphasis was on group work) discussed the ground rules of credibility evaluation of online information, asking in a whole-class setting: "When you seek information from the web, what kind of features do you check?" The students listed doubtful features, such as informal language or conflicts with other sources, whereas reputable societies and well-known experts were considered credible. In line with the normative expectation not to use online forums for searching medical facts, the students stated that "Anyone can say anything there" and claimed to look for "kinda opinions." To summarize the students' conceptions, T1 concluded: "I think we can agree that if a web page underlines mere benefits, you really need to ask why it doesn't mention any disadvantages to question the diet. I find sources presenting different views more credible than sources providing benefits only."

Shared evaluation of information for Internet searches was enabled by the collaborative settings, prompted by the selection of the topic in $\mathrm{C} 1$, inviting the students to negotiate their interests (Excerpt 3).

Excerpt 3. C1, Session 1: Evaluation based on veracity.

Miisa: This 5:2 diet looks awful: survive two days a week with 500 calories and eat the rest of the week normally!

Taru: Well, it sounds fairly-

Miisa: (reads aloud) This light diet promises fast weight loss and a longer life. Dream on!

The excerpt demonstrates the participants questioning the information provided by websites claiming a diet's mere positive impacts on health and wellbeing. In some groups, the veracity of claims was used to justify the selection of the diet as their topic: "Listen! This Mediterranean diet might work. Oh, I'd choose the Mediterranean, because it seems to be something I could like... This is real food. No weird stuff." Also in C3, some students reported their doubts: "Websites advertising or promoting a product and its positive effects tend to provide false information for real.” [I_C3_3B] 


\subsubsection{Using multiple sources}

$\mathrm{C} 1$ evidenced situational use of different sources as a member of topic group Diabetes-friendly diet confirmed when interviewed during the lesson: "We sought information from multiple sources; about the diet from the net and about diabetes as a disease from our health education textbook. And then I asked something from my parents." This comprised an implicit process of source triangulation and the use of sources according to situational information needs. Some students were able to consult their health-professional parent(s) about complex information, and occasionally those students appeared to be regarded as cognitive authorities in their group, determining what and how to write in the joint artifact.

Although the groups in C2 typically started to work with teacher-provided printed materials and links, they tended to turn to the Internet to make sense of complex terms and build a basic understanding on them (Excerpt 4).

Excerpt 4. C2, Session 2: "Strange" terms stimulate students' interests in topic group Influenza.

Outi: What is a complication?

Riina: It's like... I can't explain it. Let's google it, it's explained there. (Writes in the Google search bar) Complications of hysterectomy... Maybe it's this one... (reads aloud) Complication, in medicine, a consequence of a disease...

As evidenced in the excerpt, web pages retrieved through Google did not necessarily appear topically relevant (the term "complication" was explained in the context of hysterectomy), but nevertheless helped them to make sense of the term. Some groups, such as topic group Allergies, first consulted Wikipedia or the health education textbook to get an understanding of the concepts (such as immunological) but soon turned to teacher-provided print materials. $\mathrm{T} 2$, invited to help the group, explained the concept, but further encouraged them to "google immunological".

Also T1 instructed a group to use Google to dig deeper by themselves (Excerpt 5).

Excerpt 5. C1, Session 1: The teacher suggesting Google.

Teacher: Nuts and legumes consist of a lot of proteins. They provide all nutrients except vitamin B12, so you need to-

Veera: $\quad$ Does chicken contain vitamin B12? Or beef only?

Teacher: Well, I think so, but I'm not quite sure. I think beef contains more. You'd better to find it, soogle [google] it.

The excerpt indicates the complexity of health information, challenging the traditional role of the teacher who "knows everything" and, thus, the historical body and interaction order that people still expect to observe in classrooms.

As information can be sought from online resources that are practically limitless and created by a variety of providers, the importance of competencies of information evaluation is emphasized. In $\mathrm{C} 1$ and $\mathrm{C} 2$, using multiple sources proved to be an important practice to verify the credibility of the information, expressed e.g., "I'll check the handout for influenza here... Well, it concurs with the information provided by the other source." Interestingly, although C3 failed to induce group negotiation on the credibility of the information and was not observed in group work, some students in their reflective interview brought up the significance of using multiple sources; one should use many sources to see if they are in line with each other [I_C3_3B]. 


\section{Discussion}

The study focused on classroom information practices and ways cognitive authorities were distributed and co-constructed as part of these practices in the context of secondary school health education lessons. Cognitive authorities appeared contextual and situational but also guided by broader discourses circulating in the scene of action. As suggested by the core curriculum (Finnish National Board of Education, 2016), multiple information sources were allowed and used as a basis of knowledge construction in the observed classrooms. The classroom practices and tools directed students to turn, besides teachers, to Google-retrieved online sources, their own and others' experiences, and teacher-provided materials to build knowledge. This created opportunities for challenging the traditional classroom interaction order and the (re)distribution of cognitive authority (see Stroupe, 2014) among the teachers, students, and other information sources.

There was little evidence of explicit negotiation on information sources, but they were legitimated and delegitimated in subtle ways by both the teachers and students, not only through spoken discourse but also through broader discourses manifested, for instance, in the physical classroom arrangements and the tools that were made available. Teacher-selected sources were not challenged in the context of the school-based task. In addition to this transferred authority from the teacher, distinctions based on genre or medium (e.g., blogs, forums, leaflets) were made to (de)legitimate a particular source. These findings concur with those of Sundin and Francke (2009). Moreover, the findings suggest that the students shared certain norms that connect to recognizing authority, and valuing and creating information (Association of College and Research Libraries, 2015); for example, the use of multiple sources providing similar information, employing formal language, and reliance on reputable societies or well-known experts as information providers were implicitly emerging norms among the students. Moreover, situational use of information sources showed emergent credibility evaluation competencies.

Besides online sources, whose credibility in general was challenged by both teachers and students, the authority of information was contested mainly if the content did not seem plausible or applicable to real-life situations. This being said, group talk that appeared uncritical in terms of credibility evaluation can partly be explained by the participants' motives placed outside them: they were simply doing a school assignment. More authentic information needs, e.g., personal experiences of people close to them, resulted in more motivated negotiations. The study also unfolded the complex nature of health-related information, challenging the participants' understanding, and occasionally exceeding the teachers' expertise. Perhaps consequently, participants' evaluative talk focused on the veracity and complexity of information content rather than assessing information sources.

Overall, the task settings (e.g., schedule, tools, environments, and group settings) appeared to greatly guide the selection of information sources as well as the topic, depth, and broadness of classroom dialogue. The tasks in $\mathrm{C} 1$ and $\mathrm{C} 2$ can be regarded as relatively closedended, that is, to be addressed by presenting particular facts. Instead of prompting higher-level reasoning or shared reflection, such tasks channeled the students to find and present information that would meet the teacher's expectations, implicating a centralized notion of authority (see Whitworth, 2014). In contrast, C3 implying a non-challenging task (what, who, when, where) instantiated authority of a more distributed, participatory, and polyvocal nature (Whitworth, 2014); but the trivial task and insufficient group scaffolding resulted in scarce task-oriented talk and increasingly emerging off-task activities in the groups.

$\mathrm{T} 1$ and T2, in particular, scaffolded the groups and used panopticon events to center the talk on the topical agenda, align the discourse towards "proper" expressions, and resolve misunderstandings (see Scollon \& Scollon, 2004). Yet, rather than having traditional classroom roles, with the teacher lecturing and students positioned as passive receivers of information 
(Stroupe, 2014), the students were able to interact with each other with little teacher control and were allowed to use information sources not pre-selected by the teacher. Overall, a variety of pedagogical practices demonstrated the teachers' professional competence in the demanding settings of learner-centered activities, e.g., promoting interaction among students and within groups, prompting them to examine the topic more broadly, and bringing important issues to common discussion. Although whole-class settings can be regarded, from the perspective of learner-centered approach to learning, as an implication of traditional classroom interaction order, shared discussions proved to provide opportunities for the learning communities to develop a mutual understanding of presented concepts.

Experiences proved to engender dialogue in the classrooms, lowering the threshold to participate in and contribute to the discussion by sharing personal stories not only in groups, but also in whole-class settings (Muhonen, Rasku-Puttonen, Pakarinen, Poikkeus, \& Lerkkanen, 2016, 2017). Following Wilson's (1983) notion that typically people are considered to have cognitive authority in the sphere of their own experience (Wilson, 1983), these stories were rarely contested. The classmates' personal experiences can be considered memorable and thus, likely to result in deeper meanings and understanding of the topic (Stahl, 2006). However, learners need to differentiate between experiences and research-based information, for example, and recognize that different types of authorities can exist in different spheres of knowledge (see Association of College and Research Libraries, 2015).

A single authority model, relying heavily on the teacher or pre-selected materials, may be an option to meet tight schedules and curriculum-based learning goals. However, although pre-selected materials, such as leaflets and web links, can be viewed as relevant authentic text types encountered in everyday health information situations, they can be considered to represent intratextual information seeking from a pre-selected source and thus not the best option to help learners to become competent information seekers in everyday life situations with infinite sources and perspectives, referred to as intertextual information seeking (Sundin, 2015). Allowing a variety of information sources and encouraging students to participate by sharing experiences can make room for multi-voiced authority and create opportunities for credibility negotiation.

\section{Conclusion}

This study contributed to understanding how the "idealized" forms of multiliteracy discussed in the literature are "realized" in classrooms. It evidenced information practices implying a distribution of cognitive authority among multiple information sources and their subtle coconstruction. These practices may have potential in empowering young people to develop competencies needed to develop informed views cope with health information from various providers (see CILIP, 2018). However, by challenging the traditional classroom interaction order, they also create new demands on both teachers and students.

The findings suggest that, to ensure that learners consider the authority of information sources, they should be supported, not left to seek information on their own (Bartlett \& Miller, 2011; Knight \& Mercer, 2017), and provided with tasks that prompt shared reflection to go beyond simple factual questions (see Limberg, Alexandersson, Lantz-Andersson, \& Folkesson, 2008). Since the findings indicate conflicting information to provoke meaning-making, contradictory information could be purposefully included in learning tasks. Librarians and other information professionals could support teachers in designing such tasks and embedding meaningful information literacy instruction (Smith, 2013) into their teaching practices throughout the curriculum. These improvements may engage young people to develop their understanding on epistemic matters such as how do we know this, helping them manage in the ever-changing information environments. 
The study revealed the complexity of examining multilayered and multimodal social action in classrooms. However, employing the nexus analytical methodology proved helpful in shedding light on the interwoven elements in the observed settings: the trajectories of discourses in place, interaction order, and participants' historical bodies. Besides the participants', nexus analysis also invited the researchers to reflect their own historical bodies (deriving from their earlier experiences, expectations, and preconception) and positions in the interaction order, influencing both the social actions and their interpretations on them. The researchers' discussions with teachers and students before the observational period as well as their presence in the classrooms is bound to have affected the observed actions. Therefore, the researchers do not claim to offer any "true" explanations for the actions (see Scollon \& Scollon, 2004). Rather than generalizing the findings, the aim of this study was to understand how cognitive authorities may emerge in the context of group-based information practices in health education and offer valuable points of departure and reflection. The findings, due to the contextual and situational nature of the study in three classrooms, concern only these participants and circumstances. This study focused on observational data responding to the "what" and "how" questions of nexus analysis (Scollon \& Scollon, 2004), and leaving the more careful exploration of participants' motives ("why") to future research. Moreover, with these methods, the researchers cannot say much about information sources' influence, which is key to the concept of cognitive authority (Wilson 1983).

Acknowledging the teachers' multilayered authority roles, it is difficult to distinguish if the observed school tasks dealt with what students were assigned to do, referring to practical or pragmatic authority (Rescher, 2013) or what they accept or believe as true, instantiating cognitive authority (Wilson, 1983). Thus, the teacher's authority roles should be explored in more detail. Recognizing the nature of school-based information needs, research on young people's cognitive authority construction in other information environments is invited. The study evidenced manifold tensions in control and agency, and formal and informal discourses in contemporary school settings, calling for more research on those topics.

\section{Acknowledgements}

We would like to acknowledge the contribution of doctoral researchers MA Tuula Nygård and MA Anna-Maija Huhta in data collection, transcription, and discussions and Professor Maija-Leena Huotari for her work as the principal investigator in the Cognitive Authorities in Everyday Health Information Environments of Young People (CogAHealth) project. We also thank the reviewers for their constructive comments. The study was funded by the Academy of Finland (Grant No. 299112).

\section{References}

Alexander, R.J. (2005). Culture, dialogue and learning: Notes on an emerging pedagogy. Keynote presented at International Association for Cognitive Education and Psychology (IACEP) 10th International Conference, University of Durham, UK, 10-14 July 2005. Durham, UK. Retrieved from http://lpuae.pbworks.com/w/file/fetch/47478116/Dialogic\%20teaching.pdf

Association of College and Research Libraries. (2015). Framework for information literacy for higher education. $\quad$ Retrieved $27 \quad$ June from http://www.ala.org/acrl/sites/ala.org.acrl/files/content/issues/infolit/framework1.pdf 
Bartlett, J., \& Miller, C. (2011). Truth, lies and the Internet: A report into young people's digital fluency. London: Demos.

Binkley, M., Erstad, O., Herman, J., Raizen, S., Ripley, M., Miller-Ricci, M., \& Rumble, M. (2012). Defining twenty-first century skills. In P. Griffin, B. McGaw, \& E. Care (Eds.), Assessment and teaching of 21 st century skills (pp. 17-66). Dordrecht: Springer.

Bourdieu, P. (2014). On the state: Lectures at the Collège de France, 1989-1992. Edited by P. Champagne, R. Lenoir, F. Poupeau, \& M.-C. Rivière. (translated by D. Fernbach) Cambridge: Polity.

CILIP The Library and Information Association. (2018). CILIP definition of information literacy 2018. Retrieved from https://infolit.org.uk/ILdefinitionCILIP2018.pdf

Coiro, J., Knobel, M., Lankshear, C., \& Leu, D. J. (2008). Central issues in new literacies and new literacies research. In J. Coiro, M. Knobel, C. Lankshear, \& D.J. Leu (Eds.), Handbook of new literacies research (pp. 19-40). Mahwah, NJ: Erlbaum.

Cope, B., \& Kalantzis, M. (Eds.). (2016). A pedagogy of multiliteracies: Learning by design. Basingstoke: Palgrave MacMillan.

Diekema, A.R., Holliday, W., \& Leary, H. (2011). Re-framing information literacy: Problembased learning as informed learning. Library \& Information Science Research, 33, 261-268.

Finnish Advisory Board on Research Integrity. (2012). Responsible conduct of research and procedures for handling allegations of misconduct in Finland: Guidelines of the Finnish Advisory Board on Research Integrity. Helsinki: Finnish Advisory Board on Research Integrity.

Finnish National Board of Education. (2016). National core curriculum for basic education 2014. Helsinki: Finnish National Board of Education.

Glaser, B.G. (1978). Theoretical sensitivity: Advances in the methodology of grounded theory. Mill Valley, CA: Sociology Press.

Goffman, E. (1983). The interaction order: American Sociological Association, 1982 presidential address. American Sociological Review 48(1), 1-17.

Halinen, I., Harmanen, M., \& Mattila, P. (2015). Making sense of complexity of the world today: Why Finland is introducing multiliteracy in teaching and learning. In V. Bozsik (Ed.), CIDREE Yearbook 2015 - Improving literacy skills across Europe (pp. 136-153). Budapest: HIERD.

Hanell, L., \& Salö, L. (2015). 'That's weird, my ob-gyn said the exact opposite!': Discourse and knowledge in an online discussion forum thread for expecting parents. Tilburg Papers in Culture Studies, paper 125. Retrieved 1 January 2019 from https://www.tilburguniversity.edu/sites/tiu/files/download/TPCS_125_Hanell-Salo_2.pdf

Hirvonen, N., Nygård, T., Palmgren-Neuvonen, L., Huhta, A-M. \& Huotari, M-L. (2019). Finnish school health education viewed through an information literacy lens. In S. Kurbanoğlu, 
S. Špiranec, Y. Ünal, J. Boustany, M-L. Huotari, E. Grassian, D. Mizrachi, L. Roy (Eds.) Information Literacy in Everyday Life. 6th European Conference, ECIL 2018, Oulu, Finland, September 24-27, 2018, Revised Selected Papers (pp. 154-165). Cham, Switzerland: Springer International Publishing.

Hirvonen, N., Tirroniemi, A. \& Kortelainen, T. (2019). The cognitive authority of usergenerated health information in an online forum for girls and young women. Journal of Documentation, 75(1), 78-98.

Hongisto, H., \& Sormunen, E. (2010). The challenges of the first research paper - observing students and the teacher in the secondary school classroom. In A. Lloyd \& S. Talja (Eds.), Practising information literacy: Bringing theories of learning, practice and information literacy together (pp. 95-120). Wagga Wagga: Centre for Information Studies. Retrieved 21 September 2012 from https://blogs.sis.uta.fi/knowid/files/2010/05/Hongisto_Sormunen_PIL2010.pdf

Hult, F.M. (2015). Making policy connections across scales using nexus analysis. In F.M. Hult \& D.C. Johnson (Eds.), Research methods in language policy and planning: A practical guide (pp. 215-231). Malden: Wiley.

Hult, F.M. (2017). Nexus analysis as scalar ethnography for educational linguistics. In M. Martin-Jones \& D. Martin (Eds.), Researching multilingualism: Critical and ethnographic Perspectives (pp. 89-104). London and New York: Routledge.

Kiili, C., Leu, D.J., Marttunen, M., Hautala, J., \& Leppänen, P.H. (2018). Exploring early adolescents' evaluation of academic and commercial online resources related to health. Reading and Writing, 31, 533-557.

Knight, S., \& Mercer, N. (2017). Collaborative epistemic discourse in classroom informationseeking tasks. Technology, Pedagogy and Education, 26(1), 33-50.

Lane, P. (2014). Nexus analysis. In J.-O. Östman \& J. Verschueren (Eds.), Handbook of pragmatics: 2014 Installment (pp. 1-23). Amsterdam: John Benjamins Publishing.

Lankshear, C., \& Knobel, M. (2011). New literacies. Maidenhead: McGraw-Hill Education.

Limberg, L. (1999). Three conceptions of information seeking and use. In T. D. Wilson \& D.K. Allen (Eds.) Exploring the contexts of information behaviour. Proceedings of the second international conference on research in information needs, seeking and use in different contexts. August 13-15, 1999. Sheffield, UK (pp. 116-135). London: Taylor Graham.

Limberg, L., Alexandersson, M., Lantz-Andersson, A., \& Folkesson, L. (2008). What matters? Shaping meaningful learning through teaching information literacy. Libri, 58, 82-91.

Macleod, G., MacAllister, J., \& Pirrie, A. (2012). Towards a broader understanding of authority in student-teacher relationships. Oxford Review of Education, 38, 493-508.

Mansour, A., \& Francke, H. (2017). Credibility assessments of everyday life information on Facebook: A sociocultural investigation of a group of mothers. Information Research, 22, http://www.informationr.net/ir/22-2/paper750.html. 
McKenzie, P. (2003). Justifying cognitive authority decisions: Discursive strategies of information seekers. The Library Quarterly: Information, Community, Policy, 73, 261-288.

Martinviita, A.-M. (2017). Online community as experience and discourse: A nexus analytic view into understandings of togetherness online. (Doctoral dissertation). University of Oulu, Oulu, Finland.

Muhonen, H., Rasku-Puttonen, H., Pakarinen, E., Poikkeus, A.M., \& Lerkkanen, M.K. (2016). Scaffolding through dialogic teaching in early school classrooms. Teaching and Teacher Education, 55, 143-154.

Muhonen, H., Rasku-Puttonen, H., Pakarinen, E., Poikkeus, A.M., \& Lerkkanen, M.K. (2017). Knowledge building patterns in educational dialogue. International Journal of Educational Research, 81, 25-37.

Neal, D.M., \& McKenzie, P.J. (2011). Putting the pieces together: Endometriosis blogs, cognitive authority, and collaborative information behavior. Journal of Medical Library Association, 99(2), 127-13.

New London Group. (1996). A pedagogy of multiliteracies: Designing social futures. Harvard Educational Review 66(1), 60-93.

Norris, S., \& Jones, R.H. (2005). Discourse as action/discourse in action. In S. Norris \& R.H. Jones (Eds.) Discourse in action: Introducing mediated discourse analysis (pp. 3-14). London: Routledge.

Paakkari, L., \& Paakkari, O. (2012). Health literacy as a learning outcome in schools. Health Education, 112, 133-152.

Palsa, L., \& Ruokamo, H. (2015). Behind the concepts of multiliteracies and media literacy in the renewed Finnish core curriculum: A systematic literature review of peer-reviewed research. Seminar.Net, 11(2). Retrieved from https://journals.hioa.no/index.php/seminar/article/view/2354.

Rescher, N. (2013). Epistemic merit: and other essays on human knowledge. Berlin: De Gruyter.

Rieh, S.Y. (2010). Credibility and cognitive authority of information. In M.J. Bates \& M.N. Maack (Eds.), Encyclopedia of library and information sciences (3rd ed.) (pp. 1337-1344). London: Taylor \& Francis.

Räisänen, S. (2015). Changing literacy practices: A becoming of a new teacher agency. (Doctoral dissertation). University of Oulu, Oulu, Finland. Retrieved from http://urn.fi/urn:isbn:9789526208480

Savolainen, R. (2008). Everyday information practices: A social phenomenological perspective. Toronto: The Scarecrow Press, Inc. 
Sawyer, R.K. (2006). The new science of learning. In R.K. Sawyer (Ed.), Cambridge handbook of the learning sciences (pp. 1-16). New York: Cambridge University Press.

Scardamalia, M., \& Bereiter, C. (2006). Knowledge building: Theory, pedagogy, and technology. In K. Sawyer (Ed.), Cambridge handbook of the learning sciences (pp. 97-118). New York: Cambridge University Press.

Scollon, R. (2001). Mediated discourse: The nexus of practice. New York: Routledge.

Scollon, R., \& Scollon, S.W. (2003). Discourses in place: Language in the material world. London:Routledge.

Scollon, R., \& Scollon, S.W. (2004). Nexus analysis: Discourse and the emerging internet. London: Routledge.

Scollon, S., \& de Saint-Georges, I. (2012). Mediated discourse analysis. In J.P. Gee \& M. Handford (Eds.), The Routledge handbook of discourse analysis (pp. 66-78). London: Routledge.

Shor, I. (2014). When students have power: Negotiating authority in a critical pedagogy. Chicago: University of Chicago Press.

Smith, J.K. (2013). Secondary teachers and information literacy (IL): Teacher understanding and perceptions of IL in the classroom. Library \& Information Science Research, 35, 216-222.

Staarman, J.K., \& Mercer, N. (2010). The guided construction of knowledge: Talk between teachers and students. In K. Littleton, C. Wood, \& J. K. Staarman (Eds.), International Handbook of Psychology in Education (pp. 75-104). Bingley, UK: Emerald.

Stahl, G. (2006). Group cognition: Computer support for building collaborative knowledge. Cambridge, MA: MIT Press.

Sormunen, E., Alamettälä, T., \& Heinström, J. (2013). The teacher's role as facilitator of collaborative learning in information literacy assignments. In S. Kurbanoğlu, E. Grassian, D. Mizrachi, R. Catts, \& S. Špiranec (Eds.), Worldwide commonalities and challenges in information literacy research and practice: European conference on information literacy, ECIL 2013 Istanbul, Turkey. Revised selected papers (pp. 499-506). Heidelberg: Springer International Publishing.

Sormunen, E., Tanni, M., Alamettälä, T., \& Heinström, J. (2014). Students' group work strategies in source-based writing assignments. Journal of the Association for Information Science and Technology, 65, 1217-1231.

Stroupe, D. (2014). Examining classroom science practice communities: How teachers and students negotiate epistemic agency and learn science-as-practice. Science Education, 98, 487516.

Sundin, O., \& Francke, H. (2009). In search of credibility: pupils' information practices in learning environments. Information Research, 14, paper 418. Retrieved from http://www.informationr.net/ir/14-4/paper418.html. 
Sundin, O. (2015) Invisible search: Information literacy in the Swedish curriculum for compulsory schools. Nordic Journal of Digital Literacy, 10(4), 193-209.

Talja, S., \& Nyce, J.M. (2015). The problem with problematic situations: Differences between practices, tasks, and situations as unit of analysis. Library \& Information Science Research, 37, 61-67.

Tan, L., \& Guo, L. (2014). Multiliteracies in an outcome-driven curriculum: Where is its fit? The Asia-Pacific Education Researcher, 23(1), 29-36.

Twining, P., Heller, R.S., Nussbaum, M., \& Tsai, C.-C. (2017). Some guidance on conducting and reporting qualitative studies. Computers \& Education, 106, A1-A9.

Wilson, P. (1983). Second-hand knowledge: An inquiry into cognitive authority. Westport, CT: Greenwood Press.

Whitworth, A. (2014). Radical information literacy: Reclaiming the political heart of the IL movement. Oxford, England : Chandos Publishing.

Wohlwend, K. (2014). Mediated discourse analysis: Tracking discourse in action. In P. Albers, T. Holbrook \& A.S. Flint (Eds.), New methods of literacy research (pp. 56-69). New York: Routledge. 
Table 1. Features of Cases 1-3.

\begin{tabular}{|c|c|c|c|c|}
\hline \multicolumn{2}{|l|}{ Case } & C1 & $\mathbf{C 2}$ & $\mathbf{C 3}$ \\
\hline \multicolumn{2}{|l|}{$\mathrm{N}$} & 17 & 21 & 18 \\
\hline \multicolumn{2}{|l|}{ Group size } & $2-3$ & 3 & $4-5$ \\
\hline \multirow[t]{3}{*}{ Task } & theme & special diets & chronic/infectious diseases & physical activity \\
\hline & assignment & $\begin{array}{l}\text { why select; health } \\
\text { impacts; how to } \\
\text { prevent or manage } \\
\text { cons }\end{array}$ & $\begin{array}{l}\text { causes, diagnosis, treatment, } \\
\text { transmission, epidemiology, } \\
\text { prevention }\end{array}$ & $\begin{array}{l}\text { pros and cons; who, where, } \\
\text { when it concerns }\end{array}$ \\
\hline & output & hand-written posters & PowerPoint presentations & documentary videos \\
\hline \multicolumn{2}{|c|}{ Group work space } & one classroom & one classroom & school spaces \\
\hline \multicolumn{2}{|c|}{ Structure and scripts } & $\begin{array}{l}\text { independent group } \\
\text { work with whole- } \\
\text { class discussions }\end{array}$ & independent group work & $\begin{array}{l}\text { independent group work } \\
\text { (filming and editing } \\
\text { instructed by media school } \\
\text { educators) }\end{array}$ \\
\hline \multirow[t]{3}{*}{$\begin{array}{l}\text { Observed } \\
\text { classroom } \\
\text { activities (min) }\end{array}$} & $\begin{array}{l}\text { Information } \\
\text { seeking/knowledge } \\
\text { construction }\end{array}$ & $3 * 45$ & $3 * 45$ & $\begin{array}{l}4 * 75 \text { planning, } \\
3 * 75 \text {, filming and editing }\end{array}$ \\
\hline & Whole-class review & $3 * 45$ & $2 * 45$ & 25 \\
\hline & Total & 270 (4 h 30 min) & 225 (3 h 45 min) & $550(9 \mathrm{~h} 10 \mathrm{~min})$ \\
\hline
\end{tabular}

Table 2. Tools and sources used in Cases 1-3.

\begin{tabular}{llll}
\hline Case & \multicolumn{1}{c}{ C1 } & \multicolumn{1}{c}{ C2 } & \\
\hline ICT tools used & tablets, smartphones & laptops, tablets, smartphones & $\begin{array}{l}\text { smartphones, computers, } \\
\text { digital video cameras }\end{array}$ \\
\hline $\begin{array}{l}\text { Source } \\
\text { recommendations }\end{array}$ & $\begin{array}{l}\text { no observed recommendations or } \\
\text { limitations }\end{array}$ & $\begin{array}{l}\text { teacher-provided material and } \\
\text { recommended links; no observed } \\
\text { limitations }\end{array}$ & $\begin{array}{l}\text { no observed } \\
\text { recommendations or } \\
\text { limitations; interviews as an } \\
\text { option for information } \\
\text { seeking }\end{array}$ \\
\hline $\begin{array}{l}\text { Typical } \\
\text { information } \\
\text { sources }\end{array}$ & $\begin{array}{l}\text { health education textbook; googled } \\
\text { websites: Wikipedia, online forums, } \\
\text { and commercial sites; health care } \\
\text { providers and societies; group } \\
\text { members' own experiences }\end{array}$ & $\begin{array}{l}\text { health education textbook, } \\
\text { teacher-selected brochures and } \\
\text { official websites from Finnish } \\
\text { health authorities and } \\
\text { professionals; Wikipedia; } \\
\text { googled websites; group } \\
\text { members' own experiences }\end{array}$ & $\begin{array}{l}\text { group members' own views } \\
\text { and experiences, } \\
\text { interviewees (home } \\
\text { economics and physical } \\
\text { education teachers, peers) }\end{array}$ \\
\hline
\end{tabular}

